\title{
Jacek Poniedziałek
}

Uniwersytet Warmińsko-Mazurski w Olsztynie

\section{Stanowiska teoretyczne w socjologii regionu}

STRESZCZENIE Celem niniejszego artykułu jest wykazanie, że socjologia regionu jako wyodrębniona subdyscyplina wypracowała wiele perspektyw teoretycznych. Ich mnogość i doniosłość heurystyczna, o czym świadczy liczba badań empirycznych realizowanych z ich użyciem, stanowią o relatywnej ich dojrzałości. W związku z powyższym dokonano w prezentowanym tekście krytycznej analizy najważniejszych stanowisk teoretycznych. Zaprezentowano sekcjonistyczną koncepcję regionu, humanistyczne ujęcie regionu jako ojczyzny prywatnej, perspektywę regional science, koncepcje postmodernistyczne i instytucjonalistyczne. Krytyczna analiza dominujących w ramach socjologii regionu koncepcji z jednej strony stanowi próbę podsumowania dotychczasowych dokonań teoretycznych badaczy zainteresowanych tą problematyką, z drugiej zaś może stanowić asumpt do dalszego namysłu nad teoriami funkcjonującymi w ramach socjologii regionu i w ten sposób przyczynić się do dalszego jej rozwoju.

\section{SŁOWA KLUCZOWE}

TEORIA SOCJOLOGICZNA, SOCJOLOGIA REGIONU, STUDIA REGIONALNE, INSTYTUCJONALIZM, OJCZYZNA PRYWATNA, POSTMODERNIZM 


\section{Wprowadzenie}

Socjologia regionu jako relatywnie wydzielona subdyscyplina ugruntowała już swoją pozycję w ramach dyscypliny. Problematyka zwana zbiorczo kwestią regionalną od dziesięcioleci zaprząta głowy badaczy społecznych. O dojrzałości i wartości heurystycznej dyscypliny naukowej świadczy doskonalona w badaniach empirycznych teoria, nie inaczej jest w przypadku socjologicznych badań regionalnych. Długie lata refleksji naukowej wspartej badaniami terenowymi przyniosły wypracowanie co najmniej kilku znaczących perspektyw teoretycznych. Niekiedy powiada się, że większość koncepcji regionu to mało odkrywcze, niezborne logicznie, zapośredniczone przez wiedzę potoczną teorie wypracowane w geografii, ekonomii czy naukach politycznych (Rykiel, 2008, s. 24; Rykiel, 2011, s. 8). To sąd całkowicie nieuzasadniony. Aby to udowodnić, w prezentowanym artykule dokonam - mając za podstawę studia nad literaturą przedmiotu - krytycznej analizy najważniejszych, w moim mniemaniu, teoretycznych stanowisk w socjologii regionu.

\section{Sekcjonistyczna koncepcja regionu}

W latach 30. i 40. ubiegłego wieku problematyką regionalnego zróżnicowania życia społecznego zainteresowali się socjologowie amerykańscy. Wówczas upowszechniła się tam koncepcja ujmująca region jako „obszar geograficzny, który albo posiada pewne jednolite cechy, które różnią go od przyległych obszarów lub innych regionów, albo służy jako jednostka zarządzania i administracji” (Kwaśniewski, 1993, s. 85). Wyróżniano regiony: „a) etniczne lub kulturowe, b) przemysłowe lub miejskie, c) topograficzne lub klimatyczne, d) wyspecjalizowane gospodarczo, e) państwowe jednostki administracyjne i f) ponadpaństwowe regiony polityczne" (s. 85). Tak definiowane regiony miały stać się podstawą naukowego urządzenia i zarządzania przestrzenią. W jednej z książek poświęconych problematyce regionu, American Regionalism. A Cultural-historical Approach to National Integration, Howard W. Odum i Harry E. Moore (1938) taką koncepcję nazwali sekcjonizmem. Z uwagi na niewystępowanie na obszarze Stanów Zjednoczonych ukształtowanych historycznie odrębności regionalnych autorzy zaproponowali tworzenie regionów jako obszarów funkcjonalnych w sposób dowolny, by usprawnić zarządzanie nimi. Niemniej, jak wskazywał Alvin L. Bertrand (1952, s. 132), w tego rodzaju regionach mogą kształtować się zintegrowane zbiorowości tworzące wyróżniające ich cechy społeczne, a nawet kulturowe.

Twórcy teorii sekcjonistycznej inspirowani byli ideami przestrzeni ekonomicznej i obszaru kulturowego wypracowanymi przez Roberta E. Parka, Rodericka D. McKenziego czy Williama E. Burgessa (Miazga, 2010, s. 13). Wzmiankowani badacze, bazując na badaniach terenowych realizowanych w Chicago, stwierdzali, że ludzie trwale użytkując przestrzeń, zaspokajają tu swoje potrzeby i tworzą sieć relacji (przestrzeń biotyczną i ekonomiczną) utrzymywanych w ramach życia społecznego, które z czasem wykształcają specyficzny dla tego obszaru typ kultury (Jałowiecki, Szczepański, 2006, s. 17). Wpływ na sekcjonistyczną koncepcję regionu miała również amerykańska antropologia z przełomu XIX i XX wieku. Chodzi tu o teorię areałów kulturowych charakterystyczną dla Boasowskiego historyzmu antropologicznego. Dwaj uczniowie Franza Boasa, zaliczani do dyfuzjonizmu i historyzmu - Clark Wissler, realizujący w latach 1902-1905 badania na obszarze północnych i południowych Wielkich Równin w USA, głównie wśród plemion Czarnych Stóp i Gros Ventre, oraz Alfred Kroeber badający społeczności indiańskie Mohave, Zuni i Yurok, ludność autochtoniczną w Meksyku i Peru, doszli do wniosku, że istnieje związek pomiędzy 
uwarunkowaniami klimatycznymi i geograficznymi a cechami kulturowymi. Fizyczne i klimatyczne bariery, izolując zbiorowość, sprzyjają wytwarzaniu się swoistej kultury znaczącej jakiś obszar. Wissler i Kroeber sformułowali „teorię areałów kulturowych, czyli obszarów odznaczających się występowaniem określonych cech. Głównym zadaniem tych zabiegów było określenie szlaków i sposobów rozchodzenia się tych cech, czyli określenie dynamiki zmian w kulturach plemiennych" (Szczepański, Śliz, Geisler, Cymbrowski, 2011, s. 19). Areały kulturowe cechuje względnie prosta albo złożona ludzka aktywność, budująca w perspektywie dziejów owo zróżnicowanie społeczne, ekonomiczne i przede wszystkim kulturowe (Starosta, 1999, s. 43).

Ważnym elementem sekcjonistycznej koncepcji regionu było wskazanie na powiązania zjawisk społecznych z konkretnym terytorium, na jakim mają one miejsce. Jednakże region redukowano tylko do mających miejsce w przestrzeni fizycznej stosunków społecznych. W opisywanym tu ujęciu zupełnie pominięto problematykę społecznej i kulturowej genezy regionu oraz podmiotowego charakteru regionalnej zbiorowości. Badacze tej orientacji nie zauważali istnienia fundamentalnej dla regionu tożsamości regionalnej funkcjonującej w ludzkiej świadomości. Region zredukowano do wycinka przestrzeni fizycznej zamieszkałej przez regionalną zbiorowość powiązaną relacjami biotycznymi i ekonomicznymi, gdzie mogą w wyniku tych relacji wytworzyć się jakieś zawiązki wspólnej kultury, przy czym kultura regionu traktowana była wyłącznie jako epifenomen procesów biotycznych i ekonomicznych, będąc narządzeniem adaptowania się członków zbiorowości regionalnej do warunków panujących na zajmowanych przez nich środowiskach przestrzennych i społecznych. Region traktowano jako zjawisko wobec jednostek zewnętrzne, jako obiektywny, niemalże przyrodniczy proces adaptowania się do jakiejś przestrzeni, której granice wyznaczane są najczęściej arbitralnie. Każdorazowe przeorganizowanie przestrzeni, na przykład przez nowe ustalenie granic regionów, skutkuje po pewnym czasie nowym ukonstytuowaniem się regionu jako relacji przestrzeni biotycznej i powiązań ekonomicznych ludności. Sekcjonistyczna koncepcja regionu w swojej wersji ortodoksyjnej nie znalazła wielu naśladowców w okresach późniejszych.

\section{Ojczyzna prywatna - humanistyczna koncepcja regionu}

Do ciekawych i oryginalnych wniosków dotyczących regionu dochodzili polscy socjologowie. Jeszcze w dwudziestoleciu międzywojennym, odwołując się do ewolucjonizmu krytycznego, o regionie pisał etnograf Kazimierz Moszyński. Region przedmiotem swojego zainteresowania uczynił, czerpiąc z funkcjonalizmu i socjologii humanistycznej, Józef Obrębski, a także tworzacy w ramach socjologii kulturalistycznej Józef Chałasiński (Poniedziałek, 2016a). Najbardziej jednak znaczącą i trwałą wizję regionu w socjologii polskiej wypracował Stanisław Ossowski, ujmując go jako ojczyznę prywatną. Warszawski socjolog, bazując na wcześniej wypracowanych teoriach narodu, realizował w 1945 i 1947 roku badania wsi Dobrzeń Wielki na Śląsku. Pokłosiem śląskich badań była publikacja Zagadnienia więzi regionalnej i więzi narodowej na Śląsku Opolskim (1967). W latach 1948-1949 Ossowski podjął badania we wsiach Rumy i Dźwierzuty na Mazurach, a także Leszno i Purda na Warmii. Wyniki tych badań nie zostały opublikowane za życia uczonego. Część z nich opracowano i opublikowano pół wieku po realizacji (Traba, Sakson, 2007; Poniedziałek, 2011). „W oparciu o te badania, wcześniejsze studia nad narodem oraz przyjętą i rozbudowywaną socjologię humanistyczną, Ossowski zaproponował i upowszechnił koncepcję regionu, 
która do dziś jest w badaniach regionalnych, w szczególności w socjologii, wykorzystywana najczęściej" (Poniedziałek, 2015, s. 87).

Uczony przyjmował, że zjawiska społeczne mają początek w świadomościowym wymiarze funkcjonowania człowieka uwikłanego w fenomen życia zbiorowego. Więzi społeczne, w tym regionalne, to mający realne konsekwencje społeczne i kulturowe efekt przekonań i wyobrażeń (Ossowski, 1983, s. 47). Region zaś jest odmianą więzi społecznej, Ossowski ujmuje go jako korelat zbiorowości regionalnej, która ma poczucie odrębności „ale nie uważa się za naród; inaczej mówiąc członkowie jej nie próbują przypisać swojej zbiorowości cech narodu" (1967, s. 257). Taka zbiorowość zazwyczaj stanowi część większej zbiorowości narodowej, choć funkcjonuje dzięki więzi społecznej o charakterze regionalnym. W świadomości jej członków rodzi się dzięki osobistym kontaktom poczucie wspólnoty z innymi jej członkami oraz poczucie odrębności od tych, którzy są pod różnymi względami inni. To poczucie identyfikacji i odrębności generowane przez uświadamiane sobie wyróżniki (realnie istniejące, np. język czy specyficzne obyczaje, lub wyobrażone, np. stereotypy i mity) buduje świadomość regionalną. Ta zaś tworzy się i przybiera na sile wówczas, gdy dochodzi do kontaktu z Innym (Poniedziałek, 2015, s. 88).

Więź regionalna rozpowszechniona wśród regionalnej zbiorowości mającej poczucie swoistej odrębności dotyczy ludzi zamieszkujących konkretne, ograniczone przestrzennie terytorium. Zbiorowość, która je zamieszkuje, uznaje je za własne, wraz z jej materialnymi wyróżnikami oraz prawdziwą lub zmityzowaną historią, która się do niego odnosi. Pozytywnie waloryzuje to ograniczone terytorium wraz z zamieszkującą je zbiorowością (Kubiak, 2007, s. 84). Ten osobisty stosunek jednostki do ziemi najbliższej nazywany jest przez Ossowskiego ojczyzną prywatną. Tego rodzaju więzi społeczne, terytoria i zbiorowości stanowią stały element dziejów i chronologicznie oraz logicznie wyprzedzają narody. Korelatem narodu jest to, co Ossowski nazywa ojczyzną ideologiczną. Funkcjonuje ona nie w wyniku osobistych doświadczeń, ale żywionych przez jednostkę przekonań o uczestnictwie w większej zbiorowości, jaką jest naród.

Przed wykształceniem się narodów nowoczesnych ojczyzny prywatne pokrywały się z ojczyznami ideologicznymi. Ossowski (1984) pisze, że w wyniku kształtowania się masowych narodów, co wiąże się z rozrastaniem się zbiorowości terytorialnych, ojczyzna prywatna przestaje pokrywać się z ideologiczną, wchodząc w jej skład. Ojczyzny prywatne członków narodu mnożą się i zaczynają się różnić. W nowoczesnym narodzie regiony są na tyle odrębne, że zarówno obszar ojczyzny prywatnej, jak i jej specyfika kulturowa i świadomościowa różnią się w zależności od regionu. Regiony stanowią punkt wyjścia kształtowania się narodów, następnie są jego składowymi, różniąc się od siebie, mają wiele cech wspólnych z narodem.

Dzięki swoim badaniom Ossowski dostrzegł skomplikowaną i nieoczywistą relację pomiędzy więziami regionalnymi i więziami narodowymi, a co za tym idzie - tożsamością regionalną i tożsamością narodową. Więzi i tożsamości regionalne mogą być elementem składowym więzi i tożsamości narodowych, relacje pomiędzy nimi są niekonfliktowe, poziom regionalny podporządkowany jest poziomowi narodowemu (np. Wielkopolanie czy Górale Podhalańscy, dla których identyfikacja narodowa jest ważniejsza niż regionalna, stanowiąca wzmocnienie i uzupełnienie pierwszej). Więzi i tożsamości regionalne stanowią równie ważny i dopełniający element więzi i identyfikacji z narodem (np. Kaszub jest Polakiem, ale jego kaszubskość jest równie ważna jak polskość). Więzi i tożsamości regionalne mogą być waloryzowane wyżej niż więzi i tożsamości narodowe (np. najpierw się jest 
Ślązakiem, potem dopiero Polakiem lub Niemcem, albo najpierw się jest Warmiakiem czy Mazurem, następnie zaś Niemcem lub Polakiem). W relacjach pomiędzy więzią regionalną i narodową na pograniczach narodów i kultur, a za takie Ossowski uważał Śląsk, Mazury i Warmię, często dochodzi do dominacji więzi regionalnej nad narodową, która stanowi podstawową formę funkcjonowania w regionalnej społeczności. Na przykładzie Śląska Opolskiego badacz skonstatował, że wówczas region jako ojczyzna prywatna zaczyna pełnić funkcję ojczyzny ideologicznej.

Stanisław Ossowski zauważył również, że w przypadku gdy więź i tożsamość regionalna są równe lub wyżej stawiane niż więzi i tożsamości narodowe, częściej występuje w regionach zjawisko indyferentyzmu i zmienności narodowej. Teresa Sołdra-Gwiżdż (2014) pisze, że relacje pomiędzy różnymi grupami, Ślązakami i Niemcami a ludnością napływową, wyznaczane były przez „,korelaty świadomościowe takie jak język, pochodzenie regionalne, odmienne losy historyczne i indywidualne doświadczenia określające pamięć przeszłości grupowej”, co ukazywało „działanie socjologicznego prawa tła czyniącego Niemców bliższych Ślązakom niż Polakom, których nie rozumieli i których nazywali Ukraińcami” (s. 105). Poza czynnikami etnicznymi i kulturowymi na kształtowanie się skomplikowanych relacji regionu z narodem mają wpływ również czynniki klasowe i ekonomiczne. Więzi i tożsamości regionalne Ślązaków w badanej społeczności wykazywały się intensywnym związkiem z polskością wówczas, gdy dotyczyły samodzielnych, relatywnie dobrze sytuowanych rolników, w mniejszym zaś stopniu dotyczyło to robotników, wśród których silniejsze były więzi regionalne czy powszechniejszy był indyferentyzm narodowy.

Problematyka regionalna interesowała Ossowskiego jako element większej całości, mianowicie socjologii narodu. W tym wymiarze jego twórczość była kontynuacją rozważań nad narodem, którą tak intensywnie podejmowano w okresie międzywojennym. Analiza relacji ojczyzny prywatnej - regionu i ojczyzny ideologicznej - narodu, więzi regionalnych i więzi narodowych, tożsamości regionalnych i narodowych zawsze u Ossowskiego miała za punkt odniesienia studia nad narodem. Tym samym socjologia regionu pełniła funkcję swoistej służebnicy socjologii narodu. Współcześnie często zarzuca się tej koncepcji, że de facto zawęża region do subiektywnie odczuwanego istnienia „zbiorowości regionalnej, a jeszcze bardziej społeczeństwa regionalnego albo grupy terytorialnej" (Rykiel, 2008, s. 22). Na margines zainteresowań została zepchnięta problematyka wpływu przestrzeni fizycznej i jej właściwości na kształtowanie się regionu, typów aktywności społecznych i ekonomicznych czy szerzej - społecznych i gospodarczych wzorców funkcjonujących w jego obrębie. Nie zastanawiał się również Ossowski nad wpływem instytucji politycznych na kształtowanie więzi regionalnych i ich relacji z narodem. Wiele pomysłów badacza uznawanych za zupełnie nowe było częściowo sygnalizowanych wcześniej. Dotyczy to opisanego przez Floriana Znanieckiego procesu kształtowania się narodu i jego relacji z regionami (1990), scharakteryzowanego przez Józefa Obrębskiego świadomościowego wymiaru funkcjonowania regionu czy badanego przez Józefa Chałasińskiego związku poczucia odrębności regionalnej ze świadomością narodową (Poniedziałek, 2016a).

Pomimo powyższych uwag wkład Ossowskiego do socjologicznych badań nad regionami, tożsamościami regionalnymi i ich relacjami z narodami jest niewątpliwy. Uczulił następne pokolenia badaczy na konieczność zwracania uwagi na subiektywne wyróżniki regionu, skomplikowane i zmienne relacje różnych typów i poziomów tożsamości oraz wykazał możliwość ich zmiany. O wadze i sile zaproponowanej przez uczonego koncepcji świadczy to, że na lata dla wielu pokoleń badaczy problematyki regionalnej była ona teoretyczną 
podstawą badań empirycznych. Do dzisiaj w polskiej socjologii regionu koncepcja ojczyzny prywatnej jest najpowszechniej używana, stanowi, jak się zdaje, jedyną w pełni oryginalną perspektywę teoretyczną w subdyscyplinie. Socjologowie wykorzystywali ją do badania przemian zachodzących na Ziemiach Zachodnich i Północnych Polski przed i po 1989 roku (Posern-Zieliński, 1995, s. 304). Do badaczy problematyki regionalnej, odwołujących się do koncepcji Ossowskiego bądź powielających jego pomysły nawet wówczas gdy wprost się do jego twórczości nie odnoszą, można zaliczyć Andrzeja Saksona, badającego przemiany dokonujące się wśród Mazurów, Cezarego Olbracht-Prondzyńskiego, badającego społeczności Kaszubów, czy Elżbietę Sekułę zajmująca się badaniem przemian tożsamości regionalnej i narodowej Górnoślązaków (Obracht-Prondzyński, 2002; Sakson, 2006; Sekuła, 2009).

\section{Regional science a socjologiczne ujęcia regionu - paradygmat teorii modernizacji}

Na przełomie lat 60. i 70. ubiegłego wieku do opisu problematyki regionalnej zaczęto używać kategorii pojęciowych wyrastających z paradygmatu modernizacji. Wpływ na zwiększone zainteresowanie socjologów regionem miało powstanie regional science, ekonomicznej refleksji dotyczącej problematyki rozwoju społeczno-ekonomicznego regionów. Powstanie tego typu badań regionalnych związane jest z nazwiskiem amerykańskiego ekonomisty Waltera Isarda, badającego wpływ przestrzennie zlokalizowanych czynników rozwoju na przebieg procesów gospodarczych. Jak piszą zainspirowani wspomnianą wyżej teorią i praktyką badawczą Robert M. Maclver i Charles H. Page (1949), region to „przejaw wewnątrzpaństwowego (i międzynarodowego) funkcjonowania zbiorowości społecznych" (s. 344). Wspomniani autorzy stwierdzają, że każdy region ma specyficzne dla siebie „Właściwości ziemi, klimatu, rolnictwa i technicznej eksploatacji”. Z lektury cytowanego tekstu można się dowiedzieć, że to zintegrowany społecznie obszar zapewniający dynamiczną równowagę pomiędzy swoimi elementami składowymi. Znaczy to tyle, że

technologiczne i społeczne zmiany wprowadzone w jakiejś części regionu będą bezpośrednio lub pośrednio wywoływać zmiany w pozostałych jego częściach. Oznacza to, że region musi być dostatecznie duży, aby objąć rozmaitość interesów i działań wiejskich i miejskich, przemysłowych i rolniczych, zapewnić wewnętrzną równowagę, ale nie ekonomiczną i polityczną samowystarczalność. Z drugiej jednak strony region musi być wystarczająco mały, aby utrzymać te interesy w pewnej nadrzędnej jedności i uczynić je przedmiotem bezpośredniej zbiorowej uwagi (Maclver, Page, 1949, s. 343).

W tym przypadku region jest systemem społeczno-gospodarczym rozumianym jako przedmiot badań oraz obiekt działań mających na celu zdynamizowanie procesów rozwojowych.

Takie podejście do problematyki regionu wyrastało, jak wspominałem, z paradygmatu modernizacyjnego. Zakłada on funkcjonalność wszystkich segmentów systemu społeczno-gospodarczego i konieczność wypracowania naukowych podstaw programów stymulowania wzrostu zamożności w społeczeństwie jako całości oraz w poszczególnych regionach będących elementami systemu państwowego. W takim rozumieniu, jak podkreśla Philip McMichael (1998), regiony stanowią element systemu „zorganizowania państwa i innych instytucji społecznych wokół takiego celu, jakim jest maksymalizacja bogactwa narodowego, uzyskiwana dzięki technicznemu postępowi w przemyśle i rolnictwie" (s. 286). Te założenia mające źródła w przeddziewiętnastowiecznym merkantylizmie, ekonomicznym 
liberalizmie i społecznym ewolucjonizmie każą traktować region jako wewnętrznie zbalansowany system społeczno-gospodarczy będący częścią większego systemu państw, a następnie systemu porządku międzynarodowego (Starosta, 1999, s. 41).

Utrzymywano, że świat, poszczególne państwa oraz regiony, będą rozwijać się zgodnie z uniwersalnym wzorcem, biorąc za przykład najlepiej rozwinięte regiony i państwa świata zachodniego. Punktem wyjścia wielu koncepcji regionu, a co za tym idzie - wielu badań socjologicznych nad regionem, „były ustalenia teorii wzrostu gospodarczego. (...) W praktyce światowej bliskie relacje łączące socjologię regionalną z teorią wzrostu ekonomicznego doprowadziły do sformułowania istotnych ustaleń dla teorii rozwoju regionalnego oraz dla teorii rozwoju społecznego" (Ciechocińska, 1976, s. 202). Z przyjmowanych wówczas definicji regionu wyprowadzono wiele postulatów:

które zrodziły praktyczne potrzeby realizacji teorii wzrostu w praktyce w odniesieniu do wybranych regionów. Wzrost zapotrzebowania na ustalenia socjologii regionalnej był widoczny np. przy obserwacji ewolucji, jaka się dokonała z biegiem lat w programach wyspecjalizowanych agend ONZ zajmujących się rozwojem społeczno-gospodarczym (Ciechocińska, 1983, s. 68).

Na takich fundamentach ontologicznych zaczęto instytucjonalizować socjologię regionu jako wydzieloną subdyscyplinę. Nastąpiło to w 1970 roku na Kongresie Międzynarodowego Stowarzyszenia Socjologicznego w Warnie. Powołano wówczas Komitet do Badań Rozwoju Regionalnego i Miejskiego (Research Committee on Sociology of Urban and Regional Development). Socjologia regionu miała stać się subdyscypliną praktyczną, rodzajem inżynierii społecznej usprawniającej procesy planowania przestrzennego i gospodarczego. Na tak uprawianej nauce i polityce regionalnej cień położyły skutki kryzysu gospodarczego z przełomu lat 70. i 80. Początkowy entuzjazm towarzyszący teorii modernizacji dotyczący możliwości szybkiego, nieustającego i odwzorowanego na zachodniej trajektorii rozwojowej wzrostu globalnej gospodarki (a co za tym idzie - również gospodarek narodowych i regionalnych) oraz podążających za nimi zmian w strukturze społecznej uległ z czasem znacznemu zredukowaniu. Okazało się, że wzrost gospodarczy i transformacja struktury społecznej napotykają liczne trudności, mają różne źródła oraz często odmienny przebieg w zależności od konkretnego kontekstu społecznego, politycznego i gospodarczo-kulturowego. A tego nie uwzględniano, albowiem spychano na margines zainteresowań badawczych problematykę społeczną i kulturową. Za archaiczne i niedostatecznie naukowe uważano badania regionalne realizowane w perspektywie antropologicznej czy z użyciem ujęć zaczerpniętych z socjologii humanistycznej. Szybko się jednak okazało, że kwestie społeczno-kulturowe i polityczne (np. rozwój ruchów regionalistycznych) sprawiły, iż przyjęty wówczas kierunek rozwoju subdyscypliny okazał się ślepą uliczką. Region redukowano do wymiarów procesów gospodarczych mających w nim miejsce. Ignorowano w rozważaniach regionalnych kwestie kulturowe oraz wierzono w moc racjonalnego sterowania procesami gospodarczymi. To zaś sprawiło, że ta wersja socjologii regionu szybko okazała się niedorozwiniętą gałęzią planowania przestrzennego. Dominujący niegdyś w socjologii regionu paradygmat modernizacji stracił na znaczeniu, jednak nadal znaczna liczba prac poświęconych problematyce regionów (zwłaszcza publikacje ekonomiczne i politologiczne) explicite bądź implicite nawiązuje do tego paradygmatu (Sagan, 2011, s. 35-39). 


\section{Koncepcja regionu w perspektywie teorii centrum-peryferii}

Jedna teorii społecznych, mianowicie model centrum-peryferii, ukazuje region w kontekście procesów państwo- i narodotwórczych. To teoria inspirowana marksizmem, która odwołuje się do historii świata w kategoriach „podziału stworzonego przez kapitalizm: na przodujące gospodarczo centrum i poddane eksploatacji peryferia” (Jaskułowski, 2009, s. 144). Dojrzałą formę wspominana tu perspektywa teoretyczna osiągnęła w pracach Immanuela Wallersteina (2004). Przełożenia teorii centrum-peryferii na obszar studiów regionalnych dokonał John Friedman, który pisał, że rdzeniami (centrum) są regiony o wysokim potencjale rozwojowym, innowacyjne i bogate w zasoby, peryferiami zaś te regiony, które są pozbawione zasobów rozwojowych, będące rynkiem zbytu produktów wytwarzanych w regionach centrum-rdzenia oraz stające się zasobami taniej siły roboczej dla tychże. Są trwale zależne i peryferyjne pod względem gospodarczym, co również przynosi w konsekwencji uzależnienie o charakterze politycznym (Friedman, Alonso, 1964).

Znaczna część prac z zakresu socjologii regionu pisana w tej optyce teoretycznej odwołuje się do klasycznego w tym nurcie dzieła Michaela Hechtera Internal Colonialism. The Celtic Fringe in British National Development (1975). W tym ujęciu centra państwowe, opanowane przez kształtujących to państwo, a co za tym idzie - i narody, nacjonalistów, podporządkowują sobie terytoria leżące na peryferiach jednostki państwowej bądź nawet tereny, które wcześniej nie były poddane jurysdykcji tego państwa. Centrum zaczyna kontrolować w wyniku podboju militarnego czy gospodarczego politycznie i gospodarczo te obszary, poddając je intensywnym procesom akulturacyjnym, przystosowując odmienne kulturowo zbiorowości do jednolitego narodowego wzorca. Z czasem większa część tej zbiorowości „zaczyna być w wyniku procesów akulturacyjnych realizowanych w procesie budowania narodu lojalna wobec centrum" (Fitjar, 2009, s. 6).

Jednakże część tej zbiorowości podejmuje walkę z tego rodzaju kolonizacją, próbując odzyskać polityczną i ekonomiczną kontrolę nad swoim terytorium. Jak twierdzi Stein Rokkan (1975, s. 72), chcący odzyskać kontrolę nad owym terytorium znaczący aktorzy społeczni w regionie powielają strategię używaną przez nacjonalistów w procesach budowania narodu i państwa narodowego (state and nation building strategy). W ten sposób obszar regionu staje się terytorium etnicznym dla zbiorowości, która chce politycznej samodzielności. Po to, aby ustanowić regionalną differentia specifica, poszukuje się wyróżników społecznych i kulturowych (język, dzieje, zwyczaje), legitymizuje się w ten sposób działania zmierzające do odzyskania (bądź uzyskania) politycznego samostanowienia i gospodarczej kontroli nad swoim terytorium. Michael Keating (2003) podkreśla, że w tym celu dokonuje się polityzacji istniejącej bądź wykreowanej odgórnie (z użyciem zastanych lub wykreowanych elementów) tożsamości regionalnej.

Region w tym ujęciu jest więc państwem i narodem in statu nascendi, to zbiorowość zlokalizowana przestrzennie, odrębna etnicznie i kulturowo od reszty populacji państwa, eksploatowana gospodarczo, mająca polityczne ambicje ustanowienia samoistnego bytu państwowego. Ta niezwykle cenna konstatacja wprowadza do studiów nad regionem zasadne twierdzenie mówiące, że pomimo licznych przemian nieusuwalną cechą państwa współczesnego jest jego terytorialne zróżnicowanie, gdy jednym z najistotniejszych elementów budujących ten podział są regiony. Owo zróżnicowanie, jak podkreśla Manuel Castells (2008, s. 303), cały czas odtwarzane jest przez nieusuwalne sprzeczności istniejące pomiędzy regionami a centrami państw. Jednakże ta perspektywa nadmiernie polityzuje i ekonomizuje zjawiska regionalne. Nie zauważa się tu regionów, w których brak politycznych 
aspiracji do ustanowienia własnego państwa lub chociażby autonomii regionalnej. W rzeczywistości jest perspektywą każącą spoglądać na regiony tylko jak na wewnętrzne kolonie mające charakter narodów, którym nie udało się ustanowić własnych państw. Dodatkowo nie uwzględnia się faktu, że regiony kształtują się na obszarach kolonizowanych i gospodarczo eksploatowanych, jak również na obszarach centrum i terytoriach przodujących gospodarczo. W wielu przypadkach konflikt pomiędzy regionem a państwem generowany jest przez odmienności kulturowe i etniczne. Często cele nie tylko ekonomiczne, lecz także kulturowe tych dwóch podmiotów są rozbieżne, to zaś niejednokrotnie skutkuje „ich agregacją w formie z(re)konstruowanych tożsamości” (Castells, 2008, s. 304). To z kolei powoduje budowanie regionów nie wokół kwestii ekonomicznych i politycznych, ale w oparciu na nowej regionalnej etniczności, kształtowanej na podstawie istniejącego dziedzictwa kulturowego bądź jego twórczej rekonstrukcji (Konarski, 2004).

\section{Zwrot postmodernistyczny w socjologii regionu}

Załamanie się dominacji paradygmatu modernizacyjnego przyniosło ożywienie zainteresowania problematyką regionu w socjologii. Wraz z rozwojem podejść postmodernistycznych zaczęto przesuwać zainteresowanie z tego, co uniwersalnie uwzorowane i powtarzalne, na rzecz tego, co unikalne i odmienne. Zostało to wywołane kryzysem Wielkich Narracji zarówno w ideologii, jak i nauce (Lyotard, 1997). Dowartościowano podmiotowość aktora społecznego, jednostkowego i zbiorowego. Regiony w tej perspektywie ponownie znalazły się w orbicie zainteresowań socjologów i przedstawicieli innych dyscyplin społecznych. Zauważono, że niemożliwe jest systemowe wyjaśnienie działania całych społeczeństw oraz opis ich ewolucji zgodnie z uniwersalnym wzorcem. Przyjęto, że zjawiska społeczne w dużej mierze są unikatowe w czasie, a nade wszystko w przestrzeni (Zarycki, 2000, s. 7).

Region w tym ujęciu to zbiorowość ludzka o charakterze wspólnoty wyobrażonej, spajana tożsamością odnoszoną do znaczącej kulturowo przestrzeni, którą charakteryzuje wyjątkowa przeszłość. To unikatowa jakość odznaczająca się niepowtarzalnymi cechami społecznymi i kulturowymi, odrębną historią, swoistą trajektorią rozwoju społecznego i gospodarczego. Niemożliwe jest więc stworzenie uniwersalnej teorii regionu, możliwy jest tylko gęsty opis regionów konkretnych. Wraz z narastającą popularnością perspektywy postmodernistycznej w naukach społecznych wzrosło również zainteresowanie miejscem, przestrzenią kulturowo przez swoich mieszkańców znaczoną i zwrotnie na nich oddziałującą. David Harvey (1989) powiada, że przestrzeń w ogóle, w tym przestrzenie najbliższe, lokalna, a także regionalna, wraz z powiązanymi interakcjami, dla których te przestrzenie są niezbędnym fizycznym i społeczno-kulturowym podłożem, „stanowią ramę doświadczeń, dzięki którym uczymy się, kim i czym jesteśmy w społeczeństwie" (s. 214).

Należy tu również wspomnieć o inspiracjach, jakie płyną dla socjologii regionu z prac z zakresu geografii humanistycznej, gdy region jest zjawiskiem społecznym, „staje się bowiem środowiskiem człowieka dopiero wtedy, gdy ten ostatni staje się centralnym elementem otaczającego świata" (Rykiel, 2011, s. 94). Region jest więc swego rodzaju rezultatem społecznych praktyk mających dualną formę interakcji i nadawania znaczenia środowisku przyrodniczemu, krajobrazowi architektonicznemu oraz kulturze ideacyjnej związanej z pewnym obszarem. Region jest zatem czymś, co Yi-Fu Tuan (1987, s. 75) nazwał miejscem, które jest tworzone przez ludzi w procesie nadawania znaczeń i zwrotnie kształtuje ich nastawienia, wzory interakcji i tożsamości. Wpływ na to stanowisko, a więc i w pewnym 
sensie na socjologiczny ogląd regionu, miały również prace z zakresu semiotyki i semiologii oraz studia z zakresu proksemiki.

Z drugiej strony część ponowoczesnych nauk społecznych bezpośrednio lub pośrednio a contrario do stanowiska zarysowanego wyżej unieważnia znaczenie miejsca i przestrzeni, również regionalnej. Stosując metaforę płynu i płynności, stwierdza się, że to, co rzeczywiście we współczesnym globalizującym się świecie jest faktem, to upłynnione stosunki społeczne, oderwane od przestrzennego uwiązania i narodowej oraz regionalnej lojalności. W skrajnej postaci tego stanowiska, reprezentowanej przez Richarda O’Briena, deprecjonuje się ważność przestrzeni, miejsca i umiejscowienia dla społecznej praktyki tworzenia regionu. Wyraża to sławna fraza konstatująca koniec geografii (1992). John Urry (2009, s. 45-52) stwierdza, że przestrzenie znaczące, a takimi były regiony (jako zintegrowane zbiorowości społeczne, kulturowo specyficzne i stabilizowane przez zakotwiczenie w przestrzeni), ustępują miejsca przestrzeniom przepływów, społeczeństwa zaś w miejscu (w tym regiony) stają się zbiorowościami w ruchu, przekształcając się w społeczeństwa mobilności.

Miejsca antropologiczne, czyli regiony jako przestrzenne korelaty zintegrowanych zbiorowości regionalnych tworzących własną kulturę i tożsamość, zaczynają być zastępowane przez sieć nie-miejsc. Francuski antropolog Marc Augé (2010) stwierdza, że nie-miejsca tworzą specyficzne więzi, kultury i tożsamości odzierające współczesnego człowieka z tradycyjnych form identyfikacji i zakorzenienia. Regiony tracą moc formowania świadomości jednostek, oddając pole nie-miejscom pozbawionym tradycyjnych właściwości. To świat lotnisk, centrów handlowych czy autostrad z przyległościami. W wyniku tej swoistej deterytorializacji, a także, jak utrzymuje Arjun Appadurai (2005), powiązanej z nią detradycjonalizacji, region jako miejsce tworzenia i transmitowania określonych tradycji przestaje determinować losy jednostek, które współcześnie kształtowane są przez pejzaże kreowane przez globalne przepływy etniczne, medialne, technologiczne i ideologiczne. Te pejzaże mające płynne granice i nieregularne formy nie tworzą żadnych trwałych relacji, ale kreują społeczne światy, które powstają zależnie od kontekstu i pozycji zaangażowanych w nie jednostek. W tej perspektywie region jako wpisana w znaczącą przestrzeń wspólnota kulturowa znika w świecie globalnych przepływów, albowiem region nie może istnieć wówczas, gdy „wspólnoty cechuje brak poczucia umiejscowienia" (s. 45).

Nawet pobieżny ogląd współczesnego świata pozwala stwierdzić, że rację zdają się mieć reprezentanci pierwszego z zarysowanych w tym fragmencie stanowisk. Jednym z najbardziej doniosłych skutków globalizacji jest „wyraźne osłabienie identyfikacji i więzi narodowych przy jednoczesnym nasilaniu się potrzeby wytwarzania się innych typów identyfikacji (nade wszystko, jak się wydaje regionalnych)" (Burszta, Kuligowski, 2005, s. 259). Anthony Giddens (1996, s. 336) stwierdza, że regionalne tożsamości wydają się powstawać i funkcjonować jako odpowiedź i obrona przed wzrastającym wpływem szerszego, globalnego świata na nasze życie. Identyfikacje regionalne w tym ujęciu stanowią podstawowy czynnik kształtowania się regionu jako zjawiska społecznego. Giddens pisze o symbiotycznym związku globalizacji z renesansem regionalności, stwierdza, że globalizacja dokonuje podboju, swoistej inwazji na poziomie społeczności lokalnych i regionów, nie prowadząc przy tym do ich zniszczenia. Wprost przeciwnie, nowe formy regionalnej tożsamości kulturowej i autoekspresji są przyczynowo związane z procesami globalizacji. Globalizacja wzmacnia funkcjonowanie regionów również w wyniku oddziaływań gospodarczych, które przejawiając się w zwiększeniu współzależności poszczególnych aktorów na 
poziomie ponadnarodowym, wywołują zjawisko penetrowanej suwerenności. To zaś może wywoływać „albo usamodzielnianie się jednostek wewnątrzpaństwowych [regionów - J.P.], co w konsekwencji oznacza utrzymywanie przez nie bezpośrednich relacji na poziomie ponadnarodowym z pominięciem instytucji państwowych, albo większą decentralizację działań państwa" (Tomaszewski, 2007, s. 131). Globalizacja, osłabiając instytucję państwa, wzmacnia funkcjonujące w jego ramach regiony.

Michael Sandel (1996) zauważa, że państwo w swojej obecnej formie osłabiane jest z dwóch stron. Po pierwsze, od góry przez penetrację przez globalne rynki finansowe, przepływy międzynarodowego kapitału, tworzenie się ponadnarodowych ciał politycznych. Po drugie, „poprzez coraz silniejsze aspiracje do samorządności i autonomii, wyrażane przez grupy subnarodowe” (s. 344). Wzmocnieniu ulegają zatem również regiony. „Słabnąca rola państwa umożliwiła też - jak zauważa Paweł Starosta (1999) - odsłonięcie starych problemów narodowych i regionalnych występujących w różnych społeczeństwach, skrywanych pod pokrywą subordynacji wobec instytucji państwa narodowego" (s. 43). Współczesne państwo coraz częściej skupia się na mediowaniu pomiędzy siłami globalnymi a zjawiskami oddolnymi, jednymi z nich są właśnie regiony (Wnuk-Lipiński, 2004, s. 180). Zatem, jak widać, procesy globalizacyjne wzmacniają funkcjonujące regiony, nie zaś, jak się uważa, doprowadzają do ich zanikania.

\section{Wpływ nowego instytucjonalizmu na socjologiczne koncepcje regionu}

W socjologii regionu funkcjonuje i rozwija się stanowisko, w którym na region w kontekście procesów globalizacyjnych spogląda się inaczej niż w koncepcji przedstawionej nieco wcześniej. Stwierdza się, że „państwo narodowe jest rekonfigurowane przez procesy globalne, zmieniające się relacje z rynkami i integrację europejską, a regiony znów stają się ważnym elementem polityki" (Keating, 2003, s. 11). Powoduje to wzmocnienie regionów istniejących oraz wzmożone procesy kreowania nowych regionów. Piszę w tym miejscu o instytucjonalizmie, w którym region to:

społeczna konstrukcja wyłaniająca się w procesie zbiorowego nadawania znaczeń. Instytucje pełnią tu rolę kulturowego instrumentarium. Z jednej strony przyjmują postać formalnych przepisów i praw, nieformalnych reguł i kodów obyczajowych, systemów klasyfikacji, zbiorowych wyobrażeń, idei oraz oczekiwań, z drugiej rutyn nawyków, przyzwyczajeń, schematów poznawczych i oczekiwań jednostkowych, ściśle powiązanych z regułami życia zbiorowego. [Region to - J.P.] osadzony kulturowo proces budowy instytucji odnoszonych do określonego terytorium (Bukowski, 2011, s. 9).

Jak pisze Keating, region to typ przestrzeni nieuchwytnej (elusive space), jako że charakteryzuje się wieloma formami występowania, różnym typem powiązań wewnętrznych i zewnętrznych (2003, s. 9). Z jednej strony regiony coraz częściej przejmują niektóre funkcje państwa: regulacyjne, moderacyjne, integrujące i mobilizacyjne - również w sensie politycznym. Z drugiej strony ze społecznościami lokalnymi regiony łączą „cechy charakterystyczne dla miejsca: gęstość powiązań społecznych i gospodarczych, swoistość postaw, obyczajów, tradycji, specyficzne cechy kapitału społecznego. W ten sposób region nabiera znaczenia jako z jednej strony przestrzeń funkcjonalna, z drugiej jako przestrzeń kulturowa, korelat zbiorowej identyfikacji” (Bukowski, 2006, s. 75). Osłabianie mocy państw narodowych sprawia, że region staje się dążącą do względnej samodzielności przestrzenią polityczną i gospodarczą. Zdaniem Ivo Streckera (1994), w wyniku procesów etnicyzacji (czy 
reetnicyzacji) wielu zbiorowości regionalnych dochodzi do znacznego wzmocnienia komponentów kulturowych poszczególnych regionów. Regiony stają się coraz silniejszym, często konkurującym z państwem narodowym, elementem nowego globalnego ładu.

Opisana tu perspektywa została zainspirowana przez rozwijający się w ostatnich latach w socjologii nowy instytucjonalizm, z którym wiążą się takie nazwiska, jak Victor Nee, James G. March czy John Mayer (Jasińska-Kania, 2006, s. 550-551). Znaczący wpływ na prezentowaną tu perspektywę miały również prace, których autorem jest ekonomista Douglass C. North, jeden z najważniejszych przedstawicieli perspektywy instytucjonalnej w naukach ekonomicznych (North, 1991). Znaczny wpływ na wykształcenie się instytucjonalnej perspektywy w socjologii regionu miał socjologiczny konstruktywizm, z klasycznymi studiami Petera Bergera i Thomasa Luckmanna na czele (Berger, Luckmann, 2010). Nie bez znaczenia jest w tym przypadku również kulturowy zwrot w ekonomii regionalnej, gdzie, jak pisze Iwona Sagan (2011), regiony traktuje się jako dynamiczne zjawiska społeczne formowane w powiązanej

sekwencji zdarzeń, która wynika ze specyfiki relacji społecznych właściwych danemu regionowi, które to relacje z kolei są reprodukowane. Regiony powstają i rozwijają się w wyniku regionalnej społecznej interakcji, będąc jednocześnie warunkiem koniecznym i efektem relacji społecznych między jednostkami, grupami i instytucjami zachodzących w konkretnym fragmencie przestrzeni (s. 39).

Region kształtowany jest przez fazowy proces mający charakter społeczno-przestrzenny. Najpierw wyłania się przestrzeń regionu, następnie zbiorowość regionalna wypracowuje specyficzną tożsamość regionalną i swoiste zasoby symboliczne, w dalszej części wykształca się oprzyrządowanie instytucjonalne regionu, aż w końcu region ulega stabilizacji. Uzyskuje status jednostki administracyjnej, z wyznaczonymi granicami i funkcjami, w jego ramach zbiorowość uzyskuje wspólną tożsamość poprzez wypracowanie wspólnego zasobu symbolicznego legitymizowanego przez praktyki formalnych instytucji regionalnych. Stabilizacja regionu odbywa się poprzez prowadzenie stałej działalności praktycznej i symbolicznej reprodukującej terytorium regionu, budującej świadomość mieszkańców oraz utrzymującej zestaw instytucji temu służący. Do czynników dezinstytucjonalizujących zaliczane są między innymi depopulacja, upadek gospodarczy, a przede wszystkim utrata statusu jednostki administracyjnej (Rykiel, 2008, s. 32). W literaturze przedmiotu największe dokonania w tej perspektywie przypisywane są, nie bez racji, fińskiemu badaczowi Anssi Paasiemu (Paasi, 1991).

Niewątpliwą zaletą perspektywy instytucjonalnej jest wskazanie na relacyjny i procesualny charakter funkcjonowania regionu oraz na kluczową rolę instytucji regionalnych w procesie konstytuowania się regionu. Niezwykle ważne jest podkreślenie powiązań pomiędzy zbiorowościami, instytucjami i terytorium (Poniedziałek, 2016b). Pomimo znacznych walorów poznawczych tej koncepcji można jej zarzucić fetyszyzację perspektywy top-down, czyli przypisywanie nadmiernej roli w procesie kreowania regionu instytucjom formalnym (np. administracji regionu), przy założeniu biernej postawy zbiorowości, akceptującej narzucane odgórnie symbole czy wzorce praktyk (Paasi, 2002). Kolejnym z jej mankamentów jest założenie uniwersalności procesów instytucjonalizowania się regionów, abstrahowanie od konkretnych historycznych i kulturowych uwarunkowań, skupienie się tylko na rozwoju regionu przy zaniechaniu dociekań dotyczących jego genezy (Paasi, 2001). 
Jak zauważa Rick Fawn, proces tworzenia regionów w tej perspektywie (region-building) jest lustrzanym odbiciem procesu budowania narodu (nation-building) (2009, s. 31). Regiony kreowane są przez intelektualistów i działaczy regionalnych, wykorzystujących te same strategie (przemoc symboliczną, masowe media, wynajdywanie tradycji) i czynniki (mity, język, ideologie), co nacjonaliści w procesie budowania narodu. To podejście do problematyki regionu syntetycznie ujmuje jeden z prominentnych przedstawicieli tej teoretycznej optyki, Iver Neumann (2001), dla którego „regiony są wytwarzane przez politycznych aktorów jako polityczne programy, nie są zjawiskami istniejącymi w rzeczywistości, które tylko czekają na to, by być odkryte" (s. 71). Regiony są więc społecznymi artefaktami, które istnieją tylko dzięki temu, że są wytworzone odgórnie i zaszczepiane w świadomości ludzi dzięki narzędziom przemocy symbolicznej. Przez wyżej wskazane praktyki ludzie w interakcjach budują poczucie faktycznego istnienia regionu, który w rzeczywistości jest tylko ich wyobrażeniem i zbiorem reprodukowanych na określonej przestrzeni społecznych praktyk. Do konstruktywistów w instytucjonalizmie można zaliczyć z całą pewnością wymienionego wcześniej Paasiego, dla którego region to wytworzona niemalże ex nihilo w zainicjowanym przez aktorów regionalnych procesie instytucjonalizowania, reprodukowana społecznie i instytucjonalnie praktyka dyskursywna, mogąca zdarzyć się wszędzie, na dowolnie wyznaczonym w wyniku odgórnych zabiegów terytorium (Paasi, 2013).

Wspomnieć również należy o historycznym konstruktywizmie kulturowym obecnym w ramach perspektywy instytucjonalnej, gdy analizie poddaje się proces instytucjonalizowania się regionu oraz budowania strategii rozwoju i jej wdrażania z użyciem specyficznie rekonfigurowanych przez znaczących aktorów regionalnych treści kulturowych traktowanych jako czynniki rozwoju. Znaczącym dokonaniem teoretycznym i empirycznym jest w tym przypadku dzieło autorstwa Michaela Keatinga, Johna Loughlina i Krisa Deschouwera Culture, Institutions and Economic Development. A Study of Eight European Regions (2003). Zakłada się tu, że regiony zaczęły instytucjonalizować się w określonym momencie historii, w sprzyjających dla siebie okolicznościach (wykształcenie się jakiejś jednostki o charakterze politycznym na danym obszarze, wykrystalizowanie się specyficznej kultury itp.), trwają reprodukowane w społecznych interakcjach, kulturowych zasobach symbolicznych i są potwierdzane politycznymi praktykami. Są więc tym, co zostało nazwane przez Fernanda Braudela (2006) strukturami długiego trwania. Regiony w tym rozumieniu albo współistnieją z narodami, albo są ich początkiem, ponieważ to z nich w procesach integracyjnych i w wyniku unifikacji kulturowej tworzą się często nowoczesne narody i nowoczesne państwa (Keating, 1997). Tu szczególny nacisk kładzie się na długie trwanie regionów, ich konkretną historyczną genezę, a nie ich niedawną, bo nowoczesną proweniencję. Podkreśla się gradualizm, nie zaś świadomy polityczny akt ich inicjowania, wskazując na poszczególne stadia rozwoju oraz stopniowe narastanie zjawisk kulturowych i społecznych, które w efekcie wytworzą region jako konfigurację procesów społeczno-przestrzennych.

W tym ujęciu regiony są wytworem długiego trwania oraz społecznych i politycznych praktyk zmierzających do ich odtwarzania, a nawet zmiany. Takie połączenie podmiotowości przypisywanej jednostkowym i zbiorowym aktorom społecznym, charakterystyczne dla konstruktywizmu instytucjonalnego, z determinującym i ukierunkowującym funkcjonowanie regionu, odziedziczonym z przeszłości zasobem wartości kulturowych, społecznych oraz materialnych można odnaleźć w podejściu zwanym instytucjonalizmem historycznym (zwanym też ewolucyjnym). Takie ujęcie jest motywem przewodnim analiz i studiów regionalnych The Making of Regions In Post-Socialist Europe: The Impact of Culture, Economic 
Structure and Institutions, wydanych pod redakcją Melanie Tatur (2004). Tutaj region traktuje się jako zbiór społeczno-przestrzennych praktyk:

kolektywną konstrukcję, dynamiczną i zasadniczo otwartą, ale podlegającą ewolucji, czyli w dużej mierze uwarunkowaną wcześniejszymi decyzjami i zdarzeniami. Innymi słowy, proces konstruowania [regionu - J.P.] nie jest ani całkowicie otwarty, ani dowolny, lecz wielorako osadzony w już zobiektywizowanych wzorach i regułach działania (Bukowski, 2011, s. 9).

W tym ujęciu przełamuje się ahistoryzm wcześniejszej wersji instytucjonalizmu, będącego jedną z form ujęć konstruktywistycznych. Podkreśla się tu historyczność i dynamiczny charakter funkcjonowania regionów. Jak zauważa Peter Taylor (1991, s. 186), regiony są konkretnymi społecznymi i przestrzennymi zjawiskami, które mogą być zrozumiałe i opisane tylko jako dynamiczne, przestrzennie ulokowane trajektorie zjawisk zależnych od wykształconych w przeszłości uwarunkowań. Regiony w tym ujęciu są społecznymi praktykami osadzonymi przestrzennie, funkcjonującymi z reguły w dłuższej perspektywie czasowej, nie mają jednakże odwiecznego charakteru. Pojawiając się w efekcie splotu korzystnych okoliczności (np. podział jakiegoś organizmu państwowego na mniejsze jednostki organizacyjne), w odpowiednich warunkach zaczynają się instytucjonalizować. To podejście umożliwiło skierowanie uwagi z „obserwacji regionów w pewnym specyficznym momencie czasu na rozumienie tego, jak się one tworzą, oraz jak w pewnym czasie znikają, robiąc miejsce innym" (Schrijver, 2006, s. 22). Dodatkowo przyjmuje się, że regiony są wytworem symbiotycznych relacji pomiędzy regionalnymi instytucjami oraz jednostkami i zbiorowościami regionalnymi będącymi podmiotami sprawczymi w procesie stanowienia regionu. W ten właśnie sposób zostaje pokonana słabość wielu opisywanych tu koncepcji przyjmujących, że region to proces determinowany przez bezosobowe siły działające ponad regionalnymi zbiorowościami. W równym stopniu za powstawanie i funkcjonowanie regionu odpowiadają regionalne instytucje i zbiorowości, relacje społeczne mające miejsce w konkretnej przestrzeni, przeszłość i współczesny kontekst, tradycje i dzisiejsze ich przekształcenia.

\section{Podsumowanie}

W prezentowanym tekście starałem się scharakteryzować najważniejsze w moim mniemaniu koncepcje teoretyczne odnoszące się do socjologicznej problematyki regionu. Nawet ich pobieżny przegląd uzmysławia fakt, że socjologiczne dyskusje nad regionem były odzwierciedleniem wielkich teoretycznych sporów i przemian w socjologii ogólnej. Można odnaleźć w socjologii regionu inspiracje marksizmem, szkołą chicagowską, teoriami modernizacji czy polską odmianą socjologii humanistycznej. Znaczny wpływ na socjologiczne koncepcje regionu miał również postmodernizm, a także nowy instytucjonalizm. W ostatnim czasie zauważalne są próby sięgania po dorobek humanistycznej geografii regionu, w efekcie pojawia się coraz więcej koncepcji interdyscyplinarnych. Nieprawdziwe są również często formułowane zarzuty dotyczące braku autonomicznej i pogłębionej socjologicznej refleksji nad regionem jako zjawiskiem społecznym. Jak starałem się dowieść, typ przestrzennego zorganizowania zjawisk społecznych był przedmiotem intensywnych dociekań teoretycznych i polem badań empirycznych, co skutkowało powstaniem wielu ciekawych i ważnych koncepcji i stanowisk. Wzrost zainteresowania problematyką regionalną, duża liczba koncepcji teoretycznych i realizowanych zgodnie z nimi badań empirycznych pozwala mieć nadzieję na dalszy, intensywny rozwój socjologii regionu. 


\section{LITERATURA}

Appadurai, A. (2005). Nowoczesność bez granic. Kraków: Universitas.

Augé, M. (2010). Nie-miejsca. Wprowadzenie do antropologii hipernowoczesności. Warszawa: Wydawnictwo Naukowe PWN.

Berger, P., Luckmann, T. (2010). Społeczne tworzenie rzeczywistości. Warszawa: Wydawnictwo Naukowe PWN.

Bertrand, A.L. (1952). Regional sociology as a special discipline. Social Forces, 31 (2), 132-136.

Braudel, F. (2006). Gramatyka cywilizacji. Warszawa: Oficyna Naukowa.

Bukowski, A. (2006). Władza, terytorium, tożsamość. Społeczne konstruowanie regionu. W: A. Bukowski, M. Lubaś, J. Nowak, Zarządzanie przestrzenią (s. 73-114). Kraków: Wydawnictwo Uniwersytetu Jagiellońskiego.

Bukowski, A. (2011). Region tradycyjny w unitarnym państwie w dobie globalizacji. Kraków: Wydawnictwo Uniwersytetu Jagiellońskiego.

Burszta, W., Kuligowski, W. (2005). Sequel. Dalsze przygody kultury w globalnym świecie. Warszawa: Muza SA.

Castells, M. (2008). Siła tożsamości. Warszawa: Wydawnictwo Naukowe PWN.

Ciechocińska, M. (1976). Socjologia regionalna w Polsce na tle światowym. Studia Socjologiczne, 4, 197-226.

Ciechocińska, M. (1978). Problematyka warunków życia w ujęciach socjologii regionalnej. Studia Socjologiczne, 4, 178-201.

Ciechocińska, M. (1983). Region jako teren badań socjologicznych. Studia Socjologiczne, 3, 61-76.

Fitjar, R.D. (2009). The Rise of Regionalism: Causes of Regional Mobilization in Western Europe. London: Routledge.

Fawn, R. (2009). Regions and their study: wherefrom, what for and whereto? Review of International Studies, 35, 5-34.

Friedman, J., Alonso, W. (1964). Regional Development and Planning. Cambridge: MIT Press.

Giddens, A. (1996). Affluence, Poverty and the Idea of Post-scarity Society. Development and Change, 27, 365-377.

Harvey, D. (1989). The Condition of Postmodernity. Oxford: Blackwell.

Hechter, M. (1975). Internal Colonialism. The Celtic Fringe in British National Development. London: Routledge.

Jałowiecki, B., Szczepański, S.M. (2006). Miasto i przestrzeń w perspektywie socjologicznej. Warszawa: Wydawnictwo Naukowe Scholar.

Jasińska-Kania, A. (2006). Neoinstytucjonalizm. W: A. Jasińska-Kania, L.M. Nijakowski, J. Szacki, M. Ziółkowski (red.), Współczesne teorie socjologiczne (s. 549-552). Warszawa: Wydawnictwo Naukowe Scholar.

Jaskułowski, K. (2009). Nacjonalizm bez narodów. Nacjonalizm w koncepcjach anglosaskich nauk społecznych. Wrocław: Fundacja na rzecz Nauki Polskiej.

Keating, M. (1997). The Invention of Regions: Political Restructuring and Territorial Government in Western Europe. Environment and Planning C, 15, 383-398. 
Keating, M. (2003). The New Regionalism in Western Europe. Cheltenham: Edward Elgar Publishing.

Keating, M. (2004). The Political Economy of Regionalism. W: M. Keating, J. Loughlin (red.), The Political Economy of Regionalism (s. 17-41). London: Routledge.

Keating, M., Loughlin, J., Deschouwer, K. (2003). Culture, Institutions and Economic Development: A Study of Eight European Regions. Cheltenham: Edward Elgar Publishing.

Konarski, W. (2004). Autonomia czy secesja? Ruchy regionalistyczne jako forma nacjonalizmu we współczesnej Europie i ich możliwy wpływ na ideę zjednoczonej Europy. W: W. Łukowski (red.), Tożsamość regionów w Polsce w przestrzeni europejskiej (s. 24-36). Katowice: Ruch Autonomii Śląska.

Kwaśniewski, K. (1993). Elementy teorii regionalizmu. W: K. Handke (red.), Region, regionalizm pojęcia i rzeczywistość (s. 75-86). Warszawa: Slawistyczny Ośrodek Wydawniczy.

Kubiak, H. (2007). U progu ery postwestfalskiej. Kraków: Universitas.

Lyotard, F.-J. (1997). Kondycja ponowoczesna. Warszawa: Wydawnictwo Aletheia.

Maclver, R.M., Page, Ch.H. (1949). Society: An Introductory Analysis. Rinehart: Michigan University.

McMichael, Ph. (1998). Globalizacja: mity i realia. W: K. Gorlach (red.), Socjologia wsi w Ameryce Północnej (s. 285-310). Toruń: Wydawnictwo Uniwersytetu Mikołaja Kopernika.

Miazga, M. (2010). Z zagadnień socjologii regionu. Lublin: Wyższa Szkoła Administracji Publicznej.

Neumann, I. (2001). Regionalism and Democratisation. W: J. Zielonka, A. Prawda (red.), Democratic Consolidation in Eastern Europe (s. 58-75). Oxford: University Press.

North, C.D. (1991). Institutions. The Journal of Economic Perspectives, 5 (1), 97-112.

O'Brien, R. (1992). Global Financial Integration. The End of Geography. London: Pinter.

Obracht-Prondzyński, C. (2002). Kaszubi - między dyskryminacją a regionalną podmiotowością. Gdańsk: Instytut Kaszubski.

Odum, H.W., Moore, H.E. (1938). American Regionalism. A Cultural-historical Approach to National Integration. New York: Harry Molt and Company.

Ossowski, S. (1967). Zagadnienie więzi regionalnej i więzi narodowej na Śląsku Opolskim. W: S. Ossowski, Dzieła, t. 3, (s. 251-300). Warszawa: Państwowe Wydawnictwo Naukowe.

Ossowski, S. (1983). O osobliwościach nauk społecznych. Warszawa: Państwowe Wydawnictwo Naukowe.

Ossowski, S. (1984). Wzory terytorialne ojczyzny w ideologii narodowej. W: S. Ossowski, O ojczyźnie i narodzie (s. 58-79). Warszawa: Państwowe Wydawnictwo Naukowe.

Paasi, A. (1991). Deconstructing Regions: Notes on the Scales of Spatial Life. Environment and Planning A, 23 (2), 239-256.

Paasi, A. (2000). Territorial Identities as Social Constructs. Hagar - International Social Science Review, 2 (1), 91-113.

Paasi, A. (2001). Europe as a Social Process and Discourse: Considerations of Place, Boundaries and Identity. European Urban and Regional Studies, 8 (1), 7-28.

Paasi, A. (2002). Place and Region: Regional Worlds and Works. Progress in Human Geography, 26 (6), 802-811. 
Paasi, A. (2013). Regional Planning and Mobilization of 'Regional Identity': From Bounded Spaces to Relational Complexity. Regional Studies, 47, 1206-1219.

Poniedziałek, J. (2011). Postmigracyjne tworzenie tożsamości regionalnej. Toruń: Wydawnictwo Adam Marszałek.

Poniedziałek, J., (2015). Wybrane koncepcje regionu w socjologii polskiej. Sprawy Narodowościowe. Seria nowa, 46, 85-106.

Poniedziałek, J. (2016a). Wybrane koncepcje regionu w socjologii i etnografii wypracowane w okresie II Rzeczpospolitej. Studia Regionalne i Lokalne, 56 (3), 5-30.

Poniedziałek, J. (2016b). Wielofazowy proces instytucjonalizacji regionu. Kultura i Edukacja, 111 (1), 11-33.

Posern-Zieliński, A. (1995). Problematyka etniczna w badaniach etnologicznych i antropologicznych. Lud, 78, 293-316.

Rokkan, S. (1975). Dimensions of State Formation and Nation Building: A Possible Paradigm for Research on Variations within Europe. W: Ch. Tilly (red.), The Formation of National States in Western Europe (s. 50-72). New York: Princeton University Press.

Rykiel, Z. (2008). Koncepcja przestrzeni i teorie regionu a wzorce uprawiania socjologii. W: Z. Rykiel (red.), Nowa przestrzeń społeczna w badaniach socjologicznych (s. 13-39). Rzeszów: Wydawnictwo Uniwersytetu Rzeszowskiego.

Rykiel, Z. (2011). Teorie regionu społecznego. W: M.S. Szczepański, A. Śliz, R. Geisler, B. Cymbrowski (red.), Socjologia regionu i społeczności lokalnych. Antologia (s. 67-110). Opole: Wydawnictwo Uniwersytetu Opolskiego.

Sagan, I. (2011). Współczesne studia regionalne - teoria i metodologia a także praktyka. W: M.S. Szczepański, A. Śliz, R. Geisler, B. Cymbrowski (red.), Socjologia regionu i społeczności lokalnych. Antologia (s. 35-48). Opole: Wydawnictwo Uniwersytetu Opolskiego.

Sakson, A. (2006). Tożsamość lokalna i regionalna współczesnych mieszkańców byłych Prus Wschodnich. Przegląd Zachodni, 1, 201-224.

Sandel, M., (1996). Democracy's Discontent. America in Search of a Public Philosophy. Cambridge, MA: Harvard University Press.

Schrijver, F. (2006). Regionalism after Regionalization: Spain, France and the United Kingdom. Amsterdam: University Press.

Sekuła, A.E. (2009). Po co Ślązakom potrzebny jest naród? Warszawa: Wydawnictwo Akademickie i Profesjonalne.

Sołdra-Gwiżdż, T. (2014). Stosunki etniczne w badaniach Instytutu Śląskiego z perspektywy jego 80-lecia. Studia Humanistyczne AGH, 13 (3), 101-113.

Starosta, P. (1999). Tożsamość regionalna w perspektywie socjologicznej. W: A. Matczak (red.), Badania nad tożsamością regionalna (s. 40-53). Łódź-Ciechanów: Krajowy Ośrodek Dokumentacji Regionalnych Towarzystw Kultury.

Strecker, I. (1994). Soft and Hard Regionalism. Sociology and Ethnology Bulletin, 3 (1), 47-52.

Szczepański, S.M., Śliz, A., Geisler, R., Cymbrowski, B. (red.) (2011). Socjologia regionu i społeczności lokalnych. Antologia. Opole: Wydawnictwo Uniwersytetu Opolskiego.

Tatur, M. (red.) (2004). The Making of Regions in Post-Socialist Europe: the Impact of Culture, Economic Structure, and Institutions. Wiesbaden: VS Verlag für Sozialwissenshaften. 
Taylor, J.P. (1991). A Theory and Practise of Regions: The Case of Europe. Environment and Planning $D, 9,183-195$.

Tomaszewski, K. (2007). Regiony w procesie integracji europejskiej. Warszawa: Wolters Kluwer.

Traba, R., Sakson, A. (2007). Przeszłość zapamiętana. Narracje z pogranicza. T. 1. Olsztyn: Borussia.

Tuan, Y.-F. (1987). Przestrzeń i miejsce. Warszawa: Państwowy Instytut Wydawniczy.

Urry, J. (2009). Socjologia mobilności. Warszawa: Wydawnictwo Naukowe PWN.

Wallerstein, I. (2004). World-Systems Analysis: An Introduction. Durham: Duke University Press.

Wnuk-Lipiński, E. (2004). Świat międzyepoki. Kraków: Wydawnictwo Znak.

Zarycki, T. (2000). O niektórych dylematach współczesnych badań nad przestrzenią społeczną. Studia Regionalne i Lokalne, 4 (4), 5-22.

Znaniecki, F. (1990). Współczesne narody. Warszawa: Państwowe Wydawnictwo Naukowe.

\section{THEORETICAL PERSPECTIVES IN REGIONAL SOCIOLOGY}

\section{KEYWORDS}

SOCIOLOGICAL THEORY, REGIONAL SOCIOLOGY, REGIONAL STUDIES, INSTITUTIONALISM, PRIVATE HOMELAND, POSTMODERNISM
SUMmaRY The goal of this article is to prove that regional sociology as a separate subfield has established a range of theoretical perspectives. Their quantity and heuristic significance, attested by the number of empirical studies which employed these perspectives, prove their relative maturity. As such, the presented paper includes a critical analysis of the most relevant theoretical perspectives. It features the selectionist concept of region, the humanistic approach to region as the private homeland, the regional science perspective, as well as postmodernist and institutional concepts. The critical analysis of the prevalent concepts within the regional sociology on one hand constitutes an attempt at summarising the theoretical achievements of the researchers interested in this subject, while on the other hand it may be an opportunity for further consideration of the theories which function within regional sociology and thus a stimulation for further development of the field. 